\title{
Research on Performance Management of Administrative Departments in Public Institutions
}

\author{
Chaohui Ma \\ West Yunnan University, Lincang, Yunnan, 677000
}

Keywords: public institutions; administrative departments; performance management

\begin{abstract}
In order to meet the actual needs of the perfect stage of the socialist market economic system, the Chinese government selects the financial management system reform as a breakthrough, and actively and steadily promotes the transformation of government functions. Its policy intention is to gradually promote the reform of the government administrative management system through scientific management system reform. The relationship between the government and the market and its position and role in the allocation of social resources will eventually build a government administrative mechanism that meets the needs of the socialist market economy. According to China's centralized monolithic state management framework, according to the division of government inter-governmental power and financial responsibility and fiscal expenditure responsibility, according to the principle of administrative contracting and territorial management, local governments assume the functions of government resource allocation and economic development, and actually assume most of the government. The supply function of public goods and public services, under the constraints of multiple systems, local governments face more severe government management crisis, financial crisis and trust crisis. From the perspective of management form, modeled on the fiscal expenditure management model of western countries, the administrative department of public institutions has initially established a public financial management framework, and gradually got rid of the fiscal expenditure management model of "re-investment, light output, low performance" of the planned economy, and fiscal expenditure performance. Management has made breakthroughs in technology, and financial expenditure efficiency, compliance and effectiveness have made great progress. From the perspective of management objectives, the status and role of China's government and market in social resource allocation still need to be adjusted. Local governments are large and growing rapidly. The basic contradiction that the financial expenditure is difficult to meet the needs of the public basic products and public services has not been effectively solved. How to promote the performance management of the financial expenditures of the administrative departments of the public institutions from the institutional level is a management problem that local governments need to study in depth and urgently need to be solved.
\end{abstract}

\section{Introduction}

Since the beginning of the century, China has increasingly faced government management crisis, fiscal crisis and trust crisis that are similar to Western countries but have different reasons. The "Decision on Comprehensively Deepening the Reform of Some Major Issues" reviewed and approved by the Third Plenary Session of the 18th Central Committee of the Communist Party of China clearly pointed out the causes of the government crisis and the solution to the problems: "The economic system reform is the focus of comprehensive deepening reform, and the core is to handle it well. The relationship between the government and the market makes the market play a decisive role in resource allocation and better play the role of the government." Because China's socialist market economic system is the government's recognition of the shortcomings of the planned economic system, it is actively constructed and carefully organized through decentralization. The sexual system has changed. In this transformation process, the government plays a central role in organizational management and reform, and plays an important role in successfully creating a miracle of China's economic and social development that is widely recognized and praised by the 
world. However, with the gradual withdrawal of the planned economic system and the gradual improvement of the socialist market economic system, the government's resource allocation function positioning and management role need to be actively adjusted and changed accordingly, relying on the power of the government system to promote and guarantee. This paper aims at the allocation and use management of government resources, and based on the theoretical system of public goods, from the perspective of public product allocation efficiency and production efficiency of public goods, this paper deeply analyzes the concept and essence of the performance management of financial expenditures of public institutions. The main position of local government in the performance management of fiscal expenditure emphasizes the institutional factors affecting the performance management of the financial expenditure of the administrative department of the public institution, closely links the performance management of fiscal expenditure with the optimal allocation of government resources, and closely links the performance management of fiscal expenditure with the efficiency of government administration. Attempts to crack the prominent contradiction between the large-scale and rapidly growing financial expenditures of the administrative departments of the public institutions and the insufficient supply of basic public goods and public services by the public, and promote the development of financial expenditure performance management of the administrative departments of the public institutions in a broader field.

\section{The Development Model of Performance Management of Financial Expenditure of Administrative Department of Public Institutions at Present Stage}

China's socialist market economic system is an economic system reform that the government carefully organizes and actively promotes through decentralization after fully recognizing the shortcomings of the planned economic system. Its core purpose is to give play to the basic role of market mechanism resource allocation. After more than 30 years of reform and development, China has built a socialist market economic system and created a miracle of China's rapid economic growth that has been widely recognized and praised by all countries in the world. It must be clearly understood that China's socialist market economy is still in a stage of perfection rather than maturity. Local governments are even considered to be the most important and unique government mechanism factor of China's economic miracle. In the overall resource allocation of society, the market mechanism still fails to fully develop its foundation. Sexual role, government resource allocation is still too much in the direction of economic development. Therefore, the "Decision on Comprehensively Deepening Reform of Some Major Issues" reviewed and approved by the Third Plenary Session of the 18th Central Committee of the Communist Party of China emphasizes that "economic system reform is the focus of comprehensive deepening reform, core It is to handle the relationship between the government and the market, so that the market plays a decisive role in the allocation of resources and better play the role of the government." Promote the performance management of fiscal expenditures, on the one hand, through the fiscal expenditure efficiency to distinguish between government mechanisms or market mechanisms to perform resource allocation functions, Promote the market to play a decisive role in resource allocation, to achieve economic stability and sustainable and healthy development; on the other hand, through the fiscal expenditure efficiency to achieve the government to make up for the market failure of the resource allocation function, the implementation of the theory of public goods supply and production separation, through contract outsourcing, etc.

With the evolution of China's political economy and society, the public public goods and services demand structure has undergone major changes. The lack of government public goods and services supply and structural imbalances are major difficulties in the allocation of government resources. The government allocates resources for economic development. More than the allocation of people's livelihood security resources. From the perspective of policy intentions, fiscal expenditure compliance management can only improve the relative efficiency and efficiency of government fiscal expenditure, but can not correct the lack of government public goods and services due to government fiscal decision-making bias. As a multi-government target, the local government, in the 
process of economic construction-oriented government transformation to public service-oriented government, in the process of economic development, infrastructure, public service and departmental demand and interest balance decision-making process, in the central government single performance appraisal subject Under the “core-minded” assessment mechanism, "political performance projects" and "image projects" in local government financial decision-making are not uncommon, overemphasizing economic development functions and urban and rural infrastructure construction, focusing on government department personnel funds and project funding guarantees and improvement of office conditions. Ignoring the public public demand preferences and public interests of the public, resulting in the rapid development of China's economy and the mismatch between urban and rural residents' public welfare, the problem of insufficient supply of public goods and services brought about by government fiscal decision-making bias has yet to be resolved. Implementing financial expenditure performance management to meet the needs of basic public goods and services, with government output and results as the guide, can allocate government resources according to the priority of public goods and services of the public, and provide a balanced and efficient government. Public goods and services.

\section{Institutional Policy Recommendations for Performance Management of Financial Expenditure of Administrative Departments}

China has entered the stage of perfecting the socialist market economy. It needs local governments to provide good quality public goods and public services to maintain the sound operation of market mechanisms and realize the decisive role of market mechanisms in resource allocation under the government's macroeconomic regulation. Therefore, the local government is required to change from "economic construction-oriented government" to "public service-oriented government", withdraw from the field of operational resource allocation, and position the government resource allocation function to make up for market failure. In the context of this economic and social transformation, the relationship between the government and the market has a decisive influence on the performance management of the financial expenditures of the administrative departments of public institutions. On the one hand, it is necessary to scientifically and rationally divide the boundaries of government and market resource allocation responsibilities. In areas where resource allocation should be carried out by market mechanisms, the performance management of local fiscal and fiscal expenditures cannot be discussed. In other words, the administrative expenditures of public institutions in this field are zero. On the other hand, fulfilling the local government's public product supply function, according to the theory of separation of public goods supply and production, through cost-benefit analysis and comparison, give full play to the efficiency advantage of market mechanism, and realize the quality improvement and quantity maximization of public goods and public services. The goal is to improve the performance level of the financial expenditure of the administrative department of the public institution.

From the perspective of inter-governmental resource allocation, the central government and local governments can form a resource allocation and distribution relationship with complementary advantages and clear responsibilities. The core factor lies in establishing a standardized intergovernmental fiscal management system, clarifying the division of intergovernmental power and financial responsibility, and exerting fiscal responsibility. The central government's basic public service equalization management supply advantage, giving play to the local government's grasp of the needs of residents in the jurisdiction, low agency costs, flexible supply of public goods production advantages, effectively avoiding local government short-term interests and unfair management defects.

Performance management of the administrative department of a public institution is the premise and basis of financial expenditure performance management. The performance management of financial expenditure is the content and means of performance management of the administrative department of a public institution. To promote the performance management of financial expenditures of administrative departments of public institutions, it is necessary to get rid of the path dependence of fiscal management reforms to drive administrative management reform. From 
the perspective of the concept of fiscal expenditure, the fiscal expenditure is positioned as the monetary expression of the government's functional activities. The degree of promotion of the performance management of the administrative department of the institution directly determines the scope and intensity of the performance management of the fiscal expenditure. Therefore, the study explores the performance management of the financial expenditure of the administrative department of the institution, emphasizes the combination of the performance management of the financial expenditure and the efficiency of the government management, and constructs the development model of the performance management of the administrative department of the institution to promote the performance management of the fiscal expenditure.

\section{Conclusion}

The performance management of financial expenditures of administrative departments of public institutions should be based on the performance management concepts and management practices of Western countries, closely combine with the development of China's socialist market economy and the status quo of public finance management, and combine the actual situation of China's administrative management and financial management. Give full play to the advantages of the central government's overall integration, the gradual adjustment of core interests, and the forced promotion of administrative power, with the financial management performance management of the administrative departments of the public institutions as the core, focusing on the equalization and performance management of local government public goods and public services, emphasizing The institutional factors of fiscal expenditure performance management closely link fiscal expenditure performance management with government resource optimization and allocation, closely link fiscal expenditure performance management with government administrative efficiency, scientifically adjust government and market relations, and properly handle central and local government financial rights. Investigate the relationship of affairs, innovate the local government administrative performance management mode, continue to promote the compliance management of the financial expenditures of the administrative departments of public institutions, and innovate the performance management mode of the administrative departments' financial expenditures, and realize the "most Low government costs, optimal public goods, the management objectives of public service-oriented government.

\section{References}

[1] Xiao Mingzheng. Correct View of Political Achievements and Systematic Review [J]. China Administration, 2004(7): 39.

[2] Wang Zhigang. Several questions about the construction of China's government performance evaluation index system [J]. Economist, 2008 (9).

[3] Li Hui. Research on the Use of Performance Evaluation Results of Chinese Government [J].Journal of Shandong Administration Institute of Economics and Management, 2008(8).

[4] Hu Xianzhi. Performance Technology and Government Administrative Performance [J]. Journal of Yunnan Administration Institute, 2006(1).

[5] Yin Shuang. On the Improvement of the Performance of Administrative Organizations [J]. Journal of Party and Government Cadres, 2009 (4). 